\begin{tabular}{|c|c|c|}
\hline & $\begin{array}{c}\text { Proceeding } \\
\text { International Conference on Islamic Educational Guidance and Counseling } \\
\text { 9 December 2021 } \\
\text { E-ISSN: 2827-9581 } \\
\text { Website: http://conference.iainsalatiga.ac.id/index.php/iciegc }\end{array}$ & $\begin{array}{l}\text { PEP } \\
\text { Hal. } 149-158\end{array}$ \\
\hline
\end{tabular}

\title{
KONSELING RELIGIUS: KEPUSTAKAAN
}

\author{
Arini Paratiwi ${ }^{1}$, Anggi Farasagitaputri ${ }^{2}$
}

${ }^{1,2}$ UIN Suska Riau

\begin{tabular}{|c|c|}
\hline Informasi Artikel & ABSTRACT \\
\hline $\begin{array}{l}\text { Penulis Korespondensi: } \\
\text { Anggi Farasagitaputri, } \\
\text { Email: paratiwiarini } \\
\text { @gmail.com }\end{array}$ & $\begin{array}{l}\text { Counseling is a form of service providing assistance to someone or } \\
\text { individuals who are experiencing mental difficulties, so that the } \\
\text { individual is able to deal with a problem he is facing. This article aims } \\
\text { to understand the basic concepts of religious counseling sourced from } \\
\text { the Qur'an and hadith. The method used in this study uses a library } \\
\text { research method or approach. Regarding what religious counseling is } \\
\text { and how to process religious counseling. Islamic belief has the } \\
\text { functions of counseling and therapy services where its philosophy is } \\
\text { based on the verse al- the Qur'an and the Sunnah of the Prophet. The } \\
\text { counseling process certainly leads to an increase in faith, worship and } \\
\text { a way of life that is blessed by Allah SWT. }\end{array}$ \\
\hline
\end{tabular}

\begin{abstract}
Keyword: Religious counseling, counselor

\begin{tabular}{l}
\hline ABSTRAK \\
Konseling merupakan suatu bentuk layanan pemberian bantuan \\
kepada seseorang atau individu yang mengalami kesulitan secara \\
mental, agar individu tersebut mampu menghadapi sebuah \\
permasalahan yang tengah dihadapinya. Artikel ini bertujuan untuk \\
memahami konsep dasar konseling rligius yang bersumber dari al- \\
qur'an dan hadis. Metode yang digunakan dalam kajian ini \\
menggunakan metode atau pendekatan kepustakaan (library \\
research). Kepercayaan islam mempunyai fungsi-fungsi pelayanan \\
konseling dan terapi dimana filosofisnya didasarkan di ayat al-qur'an \\
dan sunnah rasul. Proses konseling tentunya membawa kepada \\
peningkatan iman, ibadah serta jalan hidup yang diridhoi Allah SWT.
\end{tabular}
\end{abstract}

Kata kunci: Konseling religi, konselor

\section{PENDAHULUAN}

Konseling merupakan suatu bentuk layanan pemberian bantuan kepada seseorang atau individu yang mengalami kesulitan secara mental, agar individutersebut mampu menghadapi sebuah permasalahan yang tengah dihadapinya.

Jika diperhatikan bentuk-bentuk layanan, pendekatan dari proses konseling yang dilaksanakan di Barat khususnya di Amerika Serikat, ternyata tidak jauh berbeda cara-cara yang dijalankan oleh Rasullullah SAW dalam memberikan nasihat dan bimbingan kepada para sahabat yang mempunyai permasalahan ketika itu. tetapi disebabkan pendekatan dan penasihatan yang dilakukan Rasullulah tidak dicatat dan tidak dipublikasikan seperti halnya 
yang dilakukan oleh konselor profesional (versi Barat), maka penasihatan yang dilakukan oleh Rasulullah Saw tidak begitu dikenal oleh masyarakat dibandingakan dengan konselor Barat.

Layanan konseling pada masa Nabi didorong oleh kondisi masyarakat problematik dan kondisi budaya jahiliyah masa itu. Jadi faktor yang memfasilitasidilangsungkannya layanan konseling bagi masyarakat Arab pada waktu itu adalah situasi jahiliyah di satu sisi dan sifat atau watak ajaran Islam pada sisi yang lain. Islam adalah agama ilmu, dalam arti sebagai agama yang menjunjung tinggi nilai ilmu pengetahuan, mengajarkan prinsip-prinsip ilmu pengetahuan untuk menghantarkan manusia ke tingkat kecerdasan. Islam juga merupakan agama cahaya, dalam arti dengan petunjuk- petunjuk dan isyarat-isyarat ilmiah yang diajarkan, ia akan menjadi pedoman bagi manusia untuk merambah jalan kehidupannya menuju tujuan akhir kehidupan sesuai kehendak Allah.

Dari kisah nabi yang terdapat di dalam hadist nya, dapat dimaknai bahwa rasulullah SAW merupak seorrang konselor yang baik, dilihat dari bagaimana beliau menykapai para sahabatnya dan menyelasiakna suatu masalah yang sedang dihadapi pada masa itu. Adapun cararasulullah SAW menyikapi umatnya dengan sangat bijaksana, penuh dengan kearifan, yakni dengan menggunakan bahasa yang baik dan santun, sehingga dapat menciptakan suasana damai dengan kata-kata yang beliau tuturkan.

Nilai nilai agama yang dianut klien merupakan suatu hal yang perlu diperhatikan konselor dalam membrikan layanan konseling, sebab klien yang fanatic dengan ajaran agama mungkin sangat yakin dengan pemecahan masalah pribadinya melalui nilai ajaran agamanya. Kecenderungan masayarakat dalam mengatasi permasalahanya untuk meminta bantuan kepada agmawan itu telah terjadi di dunia barat. hal ini srupa dengan masayarakat Indonesia yang terkenal religious sejak dahulu hingga sekarang apabila memiliki permasalahan hidup lebihcondong mendatang tokoh agama sperti ustad, kyai, ulama-ulama.

Ayat-ayat al-qur'an banyak yang mengandung nilai konseling. Namun, belum tersaji secara konseptual dan sistematis. Al-qur'an memuat fakta hokum yang bersifar empiric sekaligus nilai-nilai yang bersifat filosofis sehinggan isinya mudah diungkap dan dikaitkan ke berbagai aspek realitas kehidupan termasuk dalam menagtasi masalah kehidupan yang bersumber dari aspek kejiawaan

\section{METODE}

Metode yang digunakan dalam kajian ini menggunakan metode ataupendekatan 
kepustakaan (library research), Studi pustaka atau kepustakaan dapat diartikan sebagai serangkaian kegiatan yang berkenaan dengan metode pengumpulan data pustaka, membaca dan mencatat serta mengolah bahan penelitian (Zed, 2003).

Dalam penelitian studi pustaka setidaknya ada tiga ciri utama yang penulis perlu perhatikan diantaranya: Pertama, bahwa penulis berhadapan langsung dengan teks (nash), bukan dengan pengetahuan langsung dari lapangan. Kedua, bahwa data pustaka umumnya adalah sumber sekunder, dalam arti bahwa peneliti memperoleh bahan atau data dari tangan kedua dan bukan data orisinil dari data pertama di lapangan. Ketiga, bahwa kondisi data pustaka tidak dibatasi oleh ruang dan waktu (Zed, 2003).

Berdasarkan hal diatas, maka pengumpulan data dalam penelitian dilakukan dengan menelaah beberapa Jurnal, buku serta sumber-sumber data dan atau informasi lainnya yangdianggap relevan dengan penelitianatau kajian.

\section{HASIL DAN BAHASAN}

\section{Pengertian Konseling Religius}

Kata konseling berasal dari kata "counsel" yang diambil dari bahasa Latinyaitu “counsilium", artinya "bersama" atau "bicara bersama". Pengertian "berbicara bersamasama" dalam hal ini adalah pembicaraan konselor dengan seorang atau beberapa klien (counselee). konseling pada hakikatnya adalah membantu klien untuk melakukan perubahan ke arah yang lebih baik. Perubahan itu meliputi pikiran, perasaan, dan tingkah laku. Konselor membantu klien untuk mencari cara dalam perubahan itu, namun yang melakukan perubahan adalah klien sendiri dengan penuh kesadaran dan ketulusan. Konselor hanya memberikan bantuan untukmenemukan cara mengatasi masalah tersebut. Firman AllahSwt. pada surat Ar Ra'du ayat 11 menegaskan: “Bagi manusia ada malaikatmalaikat yang selalu mengikutinya ber- giliran, di muka dan di belakangnya, mereka menjaganya atas perintah Allah.Sesungguhnya Allah tidak merubah Keadaan sesuatu kaum sehingga mereka merubah keadaan yang ada pada diri mereka sendiri. dan apabila Allah menghendaki keburukan terhadap sesuatu kaum, Maka tak ada yang dapat menolaknya; dan sekali-kali tak ada pelindung bagi mereka selain Dia” (Ar Ra'du: 11).

Senada dengan ayat di atas ditegaskan pula oleh Allah SWT. pada surat Al-Anfal ayat 53 berikut: "Siksaan yang demikian itu adalah karena Sesungguhnya Allah sekalikali tidak akan meubah sesuatu nikmat yang telah dianugerahkan-Nya kepada 
suatukaum, hingga kaum itu meubah apa-apa yang ada pada diri mereka sendiri, dan Sesungguhnya Allah Maha mendengar lagi Maha mengetahui “(Al Anfal: 53).

Diterangkan oleh Shihab (2002:568) bahwa kedua ayat di atas berbicara tentang perubahan, ayatpertama berbicara tentang perubahan nikmat, sedang ayat kedua yangmenggunakan kata apa, berbicara tentang perubahan apapun, yakni baik dari nikmat atau sesuatu yang positif menuju niqmat atau murka Ilahi atau sesuatu yang negatif, maupun sebaliknya dari negatif ke positif (abdul,2016)

Menurut walgito (1982) mendefenisikan konseling adalah suatu bantuan yang diberikan kepada individu dalam memecahkan masalah kehidupannya dengan wawancara dengan cara yang sesuai dengan keadaan individu yang dihadapi untuk mencapai kesejahteraan hidupnya. Sedangkan menurut slameto (1989), konseling merupakan salah satu teknik bimbingan. sering dikatakan bahwa konseling merupakan inti atau jantung bimbingan. konseling terutama digunakan untuk membantu mengatasi masalah psikologis, sosial, spiritual, dan moral.

Konseling religus menurut H.M. Arifin (1982) merupakan suatu usaha pemberian bantuan kepada seorang yangmengalami kesulitan baik lahiriah maupun batiniah yang menyangkut kehidupannya dimasa kini atau pun dimasa yang akan dating. Bantuan tersebut berupapertolongan di bidang mental ataupun spiritual, agar orang yang bersangkutan mampu mengatasinya dengan kemampuan yang ada pada dirinya sendiri maupun dorongan dari kekuatan iman dan taqwa kepada tuhan. Sedangkan pengertian konseling Islami menurut Musnamar adalah proses pemberian bantuan terhadap individu agar individu atau klien tersebut menyadari kembali akan eksistensinya sebagai makhluk (ciptaan) Allah yangseharusnya hidup sesuai dengan ketentuan dan petunjuk Allah, sehingga dapat mencapai kebahagiaan di dunia dan di akhirat (Hasyim \& Mulyono, 2010)

Dalam literatur Arab penggunaanistilah Konseling sering menggunakan kata Al Irsyad yang terambil dari asal kata Arsyada-Yursyidu-Irsyadan. Menurut Saiful Akhyar Lubis (2007), kata Irsyaddiartikan al huda, al dalalah yang berati petunjuk. Kata Irsyad merupakan bentuk masdhar yang memiliki arti pemberian petunjuk. Dalam bentuk fi'il tsulatsi (kata kerja yang terdiri dari tiga huruf) masdharnya adalah rusydun sering diartikan kecerdasan atau pintar. Barangkali penggunaan kata Irsyad sebagai istilah untuk menunjukkan konseling karena, proses konseling merupakan sebuah upaya untukmenularkan kecerdasan kepada orang lain agar konseli (individu yang diberi konseling) mendapatkan petunjuk dan hikmah dalam memecahkan masalah yang 
dihadapi. Selanjutnya, jika yang dimaksud oleh Lubis (2007) adalah Al huda, maka dapat diartikan petunjuk Allah (hidayah). Karena pada umumnya penggunaan kata Al huda sering disandingkan dengan petunjuk /hidayah Allah seperti dalam Q.S Al Fatihah 1:6 (Tarmizi, 2018)

Maka dapat disimpulkan konseling religious adalah suatu bantuan yang di berikan kepada sorang individu untuk menyelesaikan masalah yang sedang dihadapinya baik secara mental, sosial, spiritual dengan mendekatkan diri kepada allah SWT sehingga dapat mencapai kebahagiaan dunia dan akhirat.

Proses konseling yang dilakukan bertujuan untuk mengembalikan manusia kepada potensi dasarnya yaitu manusia yang fitri, fitri berarti kembali kepada kesucian dan kebenaran yang meliputiaspek jasmani dan rohani. Dengan kembalinya manusia kepada kondisi fitri ini, manusia akan mendapatkan kembali keceriaan hidup, kegembiraan dan kebahagiaan, baik di dunia maupun di akhirat.

\section{Konsep Dasar Konseling Religius}

Terkait dengan konsep dasar bimbingan dan konseling religius sesuai dengan kajian Abdul Hayat yang telah mengungkap ayat-ayat, khususnya tentang hakikat manusia, pribadi sehat, dan pribadi tidak sehat, dan menyajikannya secara konseptual dan sistematis tentang konseling yang berbasis pada ayat-ayat Al- Qur'an. Terkait dengan kajian tersebut, bahwa bimbingan konseling religius harus dilandasi dengan hakikat manusia menurut konsep agama (Islam).

\section{Hakikat manusia}

Menurut konsep konseling, manusia pada hakikatnya adalah sebagai makhluk biologis, makhluk pribadi dan makhluk sosial. Disamping itu Al-Qur'an jugamenerangkan manusia itu merupakan makhluk religius dan ini meliputi ketiga komponen lainnya, artinya manusia sebagai makhluk biologis, pribadi, dan social yang tidak terlepas dari nilai- nilai manusia sebagai makhluk religious (Hasyim \& Mulyono, 2010)

\section{Pendekatan religious dalam pelaksanaan konseling}

Pendekekatan religious dapat dikaitkan dengan aspek- aspek psikologis dalam pelaksanaan konseling yangmeliputi pribadi, sikap, kecerdasan, perasaan dan lain lainya yang berkaitan dengan klien dan konselor. Sehingga dalam pelaksanaan konseling, pribadimuslim tersebut memiliki prinsip-prinsip: a) Selalu memiliki prinsip dasar yaitu beriman kepada allah SWT; b) Memiliki prinsipkepercayaan, yaitu beriman kepda malaikat; c) Memiliki prinsipkepemimpinan, yaitu berimankepada nabi dan rasul; d) Memiliki prinsip 
pembelajaran, yaitu al-qur'an; e) Memiliki prinsip masa depan, yaitu beriman kepada hari akhir; dan f) Memiliki prinsip keteraturan yaitu beriman kepada ketentuan allah SWT.

Jika memiliki prinsip tersebut (rukun iman) maka pelaksanaan konseling tentu akan mengarahkan klien kearah kebenaran. Prinsip tersebut penting dimiliki oleh konselor muslim, karena akanmenghasilkan kecerdasan emosi dan spiritual (ESQ) yang sangat tinggi (Akhalkul Karimah) (Hasyim \& Mulyono, 2010). Hal ini selaras dengan firman allah SWT dalm surat Ali-Imran: 104, "Dan hendaklah di antara kamu ada segolongan orang yang menyeru kepada kebajikan, menyuruh (berbuat) yang makruf, dan mencegah dari yang mungkar. Dan mereka itulah orang-orang yang beruntung”(Qs. Ali Imran:104).

\section{Tujuan Konseling}

Secara umum tujuan bimbingandan konseling Islami slam tidakbanyak berbeda dengan tujuan bimbingan konseling ( versi Barat), yaitu sama-sama memberi bimbingan dan arahan kepada klien serta mengeluarkan klien dari permasalahan, dan perbedaanya terletak pada tujuan akhir yang ingin dicapai melalui bimbingan dan konseling umum (versi Barat) kepada Allah, memiliki ilmu pengetahuan yang luas, senantiasa beribadah/mengabdi kepada Allah, Mewujudkan diri seutuhnya (insan Kamil) seperti ungkapan tujuan di atas adalah mewujudkan diri sesuai dengan hakikatnya sebagai manusia yaitu untuk menjadi manusia yang selaras antara pengembangan diri dengan pelaksanaan fungsi dan keduduknnnya sebagai makhluk Allah (makhluk religius), makhluk individu, makhluksosial, dan makhluk social (Daulay, 2014).

Ada beberapa tentang tujuan bimbingan dan Konseling Islam sesuai dengan pendapat Aziz Salleh, diantaranya: 1) Menyelesaikan masalah yangdihadapi oleh klien.; 2) Berlakunya perubahan yangdiinginkan untuk mencapai kesempurnaan diri; 3) Membimbing untuk membuat keputusan yang bijaksana; 4) Bertindak secara logis, waras dan atas dasar keimanan dan bukan atas dasa hasutan nafsu dan syetan laknatullah. Membantu klien mewujudkan perhubungan yang baik.

Sedangkan menurut abdul hayat (2016) tujuan dari konseling adalah sebagai berikut:

1. Mendapatkan ketenangan hidup.

Klien yang telah dapat melakukan perubahan atau mengatasi permasalahan hidupnya, makaia akan lepas dari perasaan tertekan, keluh kesah dan stres menuju kepada ketenangan dan ketenteraman jiwa.

2. Menciptakan keseimbangan hidup.

Islam selalu mengajarkan kepada ummatnya agarmemiliki kehidupan yang 
seimbang. Seimbang antara jasmani dan rohani, oleh karena itu konseling Islami mendorong manusiaagar dapat menjalin hubungan baik dengan diri sendiri, orang lain, lingkungan, dan Allah Swt.

3. Mewujudkan manusia menjadi manusia seutuhnya.

Diterangkanoleh Lubis (2007) bahwa perwuju dan menjadi manusia seutuhnya adalah mewujudkan diri sendiri sesuai dengan hakikatnya sebagai manusia, menjadi manusia yang memilik keselarasan perkembangan unsur-unsur dirinya dan pelaksanaan fungsi atau kedudukannya sebagai makhluk Allah (makhluk religius), makhluk individu, makhluk sosial, dan makhluk berbudaya. Dalam Al-Qur'an diterangkan bahwa fungsimanusia diciptakan Allah SWT adalah sebagai 'abidullah dan khalifatullah (Hayat, 2007).

\section{Fungsi Konseling Religius}

Menurut Farid (2016) fungsi religi bagi manusia meliputi bebarapa hal yang diantaranya adalah sebagai berikut:

1. Fungsi Edukatif

Manusia mempercayakan fungsi edukatif pada agama yang mencakup tugas mengajar dan membimbing

2. Fungsi Penyelamatan

Agama dengan segala ajarannya memberikan jaminan kepada manusia keselamatan di dunia dan akhirat

\section{Fungsi Pengawasan Sosial}

Agama ikut bertanggungjawab terhadap norma-norma sosial sehingga agama menyeleksikaidah kaidah sosial yang ada, mengukuhkan yang baik dan menolak kaidah yang buruk

4. Fungsi memupuk Persaudaraan

Persamaan keyakinan merupakan salahsatu persamaan yang bisa memupuk rasa persaudaraan yangkuat

5. Fungsi Transformatif

Agama mampu melakukan perubahan terhadap bentuk kehidupan masyarakat lama kedalam bentuk kehidupan baru 


\section{Teknik Konseling Religious}

Praktek konseling Islam berupa aktivitas menolong sesama muslim yang mengalami permasalahan hidup. Dalam ajaran Islam, praktek ini memiliki dasar kuat sebagaimana ayatayat tentang saling membantu dalam kebaikan dan kesabaran menghadapi masalah, membantu orang lain dengan ikhas, membantu dengan hikmah, saling mendorong untuk berbuat dalam kebaikan.

Menurut Kholilulloh, dkk. (2014), tiga teknik konseling Islam: Pertama, konseling dengan tangan (kekuasaan), otoritas. Konselor memaknai tangan untuk terapi. Misalnya dengan memijat-mijatbagian leher dan pundak klien, sehingga terjadi rileksasi. Ketika klien mengalami rikes, konselor memberikan nasihat-nasihat berdasar dari data yang telah diperolehnya dari ungkapan yangdikeluhkan klien. Muslim meriwayatkan, dari Utsman bin Abil 'Ash ra, bahwasannya ia pernah mengadukanpenderitaannya kepada Rasulullah karena ia telah menemukan suatu penyakit di tubuhnya sejak ia masuk Islam. Lalu Rasulullah bersabda: "letakkanlah tangan mu pada tubuh mu yang merasa sakit, laluucapkanlah Bismillah sebanyak tiga kali dan ucapkanlah dengan kalimat aku berlindung kepada Allah dari kejahatan yang aku temui dan yang aku waspadai”. Konselor dapat juga memberikan sedikit penekanan dengan otoritasnya ketika melakukan konseling agar klien yakin atas kemampuan konselor. Kedua, konseling dengan lisan, dengan memberi nasehat, berdiskusi, wawancara dengan konseli. Dengan berdiskusi dan nasehat al Qur'an, sirah para nabi dan rasul, kisah para auliya' dan sholihindapat menginsiprasi. Ketiga, teknik doa. Sering ketika kita sowan ke kiai sepuh bukan nasehat yang dibutuhkan, tetapi doa dari kiai sepuh itulah yang dibutuhkan. Shadiya Muhamed S. Baqutayan (2012) menyatakan bahwa teknik konseling Islam juga menggunakan amalan yang sesuai alQuran dan Sunnah seperti wudlu, dhikir dan sholat. Teknik konseling tersebut digunakan sejak dulu untuk menyelesaiakan banyak masalah termasuk kesehatan mental (Akhmadi, 2016)

Teknik konseling Islam dapatmenerapkan metode spiritual (spiritualism methode) dan metode berpusat anak (client-centered method). Metode spiritual terdiri dari teknik latihan spiritual, menjalin kasih sayang, dan cerminan al-qudwah al-hasanah. Dalam metode spiritual, konselidiarahkan untuk mencari ketenangan hati denganmendekatkan diri kepada Alloh sebagai sumber ketenangan hati, sumber kekuatan penyelesaian masalah dan sumber penyembuhan penyakit mental. Diawali dengan menyadarkan konseli agar menerima masalah dengan lapang dada dan tawakal atas dasar keteguhan iman. 
Selanjutnya menegakkan potensi tauhidnya secara benar agar yakin bahwa Alloh satusatunya tempat mengembalikan masalah dan memohon pertolonganpenyelesaiannya. Metode ini dilanjutkan dengan menuntun kearah mendekati Alloh melalui amal ibadah yang dilaksanakan dengan khusu' hinggapadagilirannya mereka dapat memilikihati sehat dan jiwa tenteram, seperangkat sifat-sifat terpuji sertadapat mencapai kehidupan bahagia.

Dalam metode berpusat pada konseli, konseli dipandang memiliki hak memilih, merencanakan, memutuskan tentang perilaku dan nilai-nilai yang paling bermakna baginya. Konseli diberi kesempatan untuk mengekspresikan segala gangguan psikis yang menjadi problem, kemudian konselor menganalisis fakta-fakta psikis untuk mengusahakan kesembuhannya. Selanjutnya konseli didorong untuk berusaha sendiri memahamimasalahnya, menemukan keadaan baru dan memilih alternatif tindakan penyelesaian masalah. Konselor membantu menyediakan kondisi-kondisi yang memberikan kemudahan baginya untuk mengembangkan perilaku secara lebih produktif, sehingga konseli lebih mandiri dalam menyelesaikan masalahnya (Akhmadi, 2016).

\section{KESIMPULAN}

Konseling religius adalah suatu perjuangan pemberian bantuan kepada seorang (individu) yg mengalami kesulitan rohaniah baik mental serta spriritual supaya yang bersangkutan mampu mengatasi masalah yg dihadapinya dengan kekuatan iman dantaqwa pada allah SWT. Pendekatan religious bisa pada kaitkan dengan aspek psikologis pada pelaksanaan konseling yang pribadi, sikap, kecerdasan, perasaan, dan seterusnya yang berkaitan dengan klien dan konselor. Kepercayaan islam mempunyai fungsi-fungsi pelayanan konseling dan terapi dimana filosofisnya didasarkan di ayat al-qur'an dan sunnah rasul. Proses konseling tentunya membawa kepada peningkatan iman, ibadah serta jalan hidup yang diridhoi sang Allah SWT.

\section{DAFTAR RUJUKAN}

Akhmadi, A. (2016). Pendekatan Konseling Islam Dalam Mengatasi Problema Psikologis Masyarakat. Jurnal Diklat Keagamaan, (10)4, 375-385.

Hasyim, F. (2010). Bimbingan Dan Konseling Religius. Jogjakarta. Ar-Ruzz Media. Hayat, A. (2011). Konsep Konseling Berdasarkan Ayat-Ayat Al-Qur'an.

Yogyakarta: PT. LKiS Pelangi Aksara.

Lubis, S. A. (2007) Konseling Islami Kyai dan Pesantren. Yogyakarta: eLSAQ Press.

Marsudi, S. 2010. Layanan Bimbingan Dan Konseling Di Sekolah. Surakarta:

Muhammadiyah University Press.

Maulana, A. \& Wati, H. (2017). Konseling Religi Untuk Mengembangkan Karakter 
Konseling. Islamic Counseling, 1(2), 55-66.

Mukhlas \& Sofiana, I. K. (2021). Landasan Teori Konseling Islam. Kaisa: Jurnal Pendidikan Dan Pembelajaran, 1(1), 24-33. 